\title{
ESTETIKA A OCHRANA PŘíRODY
}

\author{
KAREL STIBRAL
}

\section{Úvod}

Ochrana přírody má kořeny $\mathrm{v}$ romantismu, kdy se začala formovat především na základě emocionální reakce na př́rodu. Jakkoliv se již v této době podíleli na prvních krocích $\mathrm{k}$ ochraně přírody i sami vědci, především naturfilosofové ${ }^{1}$ (vzpomeňme v ideové rovině $\mathrm{A}$. von Humboldta), vědecká argumentace se rozvíjí v podstatě až později, v průběhu 19. století. Ve druhé půli dvacátého století ochrana přírody sama sebe prezentuje s určitou oscilací přiklánějící se - at již v rovině „metateorii““, filosofického pozadí environmentálního přístupu [viz Binka 2011], či i v rámci „terénní praxe“ - jak k vědeckému zdůvodnění, tak i k zdůraznění emoční a všeobecně kulturní zakotvenosti ochrany př́rody.

Jednou ze složek emocionálního, ale obecně kulturního vztahu k přírodě a její ochraně je pak estetické zalíbení v př́rodě. To prošlo v průběhu novověku prudkými změnami. Vždyt ještě v průběhu 17. století byly obdivovány terény rovinaté, utvářené lidským vlivem a pokud možno co nejpravidelněji strukturované, v průběhu 18. století se začaly za esteticky hodnotné naopak považovat scenérie doslova divoké, jako pralesy a velehory. Tento trend pak vyvrcholil v romantismu, kdy se začala poprvé uvědoměle ochraňovat př́roda ${ }^{2} \mathrm{v}$ podobě jednotlivých objektů (viz i Humboldtův pojem př́rodní památka), i celých enkláv, většinou (pra)lesního charakteru (viz i náš Žofínský prales založený r. 1838). Tento trend chránit území s vysokou estetickou hodnotou přetrval v podstatě do druhé půlky 20. století, jak můžeme vidět na příkladu stále fungující sítě britských Area of Outstanding Natural Beauty (v Anglii, Walesu a Sev. Irsku) či National Scenic

\footnotetext{
1 Naturfilosofií míněno období přírodních věd, Naturphilosophie, kryjící se především v Německu s obdobím romantismu (ne tedy obecně jakákoliv př́rodní filosofie). Tento typ vědy se vyznačoval velkým odporem $\mathrm{k}$ mechanicismu, vitalismem, důrazem na celistvost vědění, kdy se často prolínal př́rodovědecký náhled s uměleckým, byla pro něj charakteristická i značná spekulativnost, navazovalo se na filosofii Kantovu, Herderovu a především Schellingovu. $\mathrm{Z}$ dnešního úhlu pohledu patřily naturfilosofové ovšem i mezi pionýry uvažování o evoluci a ontogenezi. Můžeme sem zařadit Lorenze Okena, Gottfrieda R. Trevirana, Alexandra von Humboldta, Erasma Darwina, Étienne Geoffroy-Saint Hillaira, u nás např. Jana E. Purkyně či Ladislava Čelakovského, Jiřího F. A. Buquoye a další. Viz např. Komárek [1997: 74-77], Rádl [1909: 98-101] a Jahn [2000: 290-301].

2 Ochranu různých prírodních území i jednotlivých organismů najdeme již samozřejmě dříve, ale výhradně z důvodů utilitárních (např. jako zdroj zvěře) či náboženských (posvátné území). Teprve v období romantismu najdeme ochranu přírody „pro ni samu“, snahu zachovat určité území či organismy pro ně samotné (tř̌eba vrby vykoupené malířem C. D. Friedrichem), pro jejich vlastní existenci jakkoliv zde pochopitelně můžeme najít různé antropocentrické motivy, mezi které patř́i i estetické zalíbení.
} 


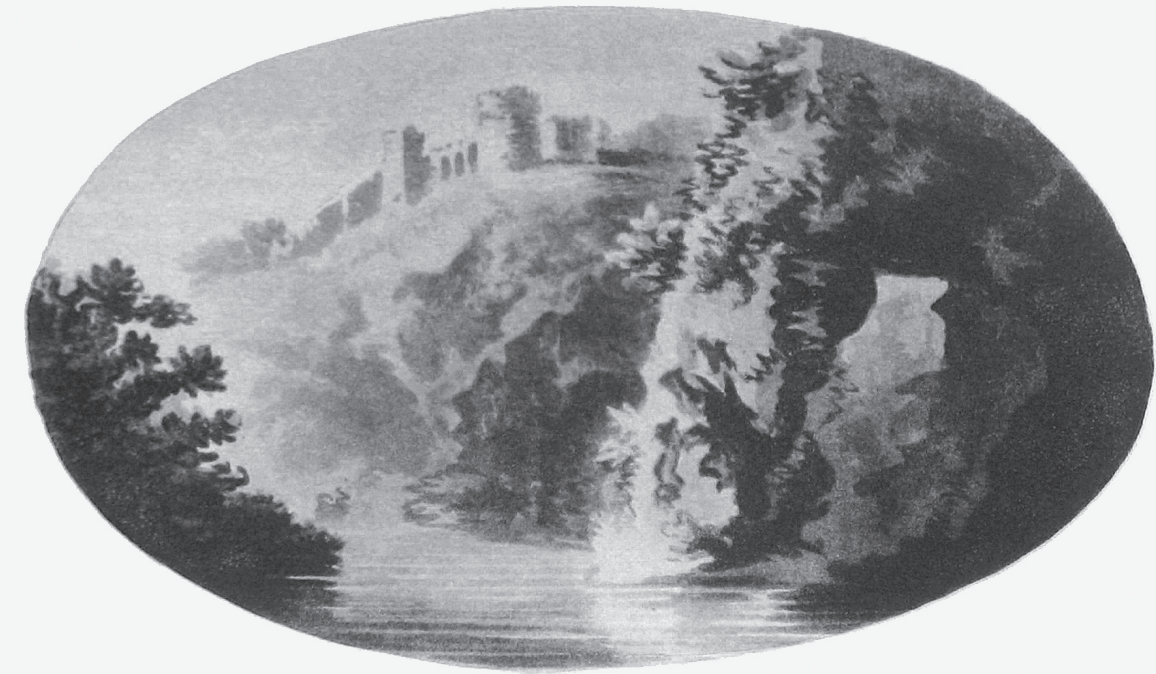

Obr. 1: Př́klad britského území Area of Outstanding Natural Beauty, údolí řeky Wye (Wye Valley) na rozhraní Anglie a Walesu. Řeka Wye (velšsky Afon Gŵ̀y) patřila již v 18. století k hlavním cílům tzv. Picturesque Tours, cest za malebnými scenériemi. Dobová akvatinta hlavního propagátora cest za malebnem Williama Gilpina z jeho Observations on the River Wye ... relative chiefly to Picturesque Beauty z r. 1782.

Area (ve Skotsku). Stejně tak najdeme estetickou hodnotu krajiny i u nás v současnosti $\mathrm{v}$ př́ípadě zákonů vztahujících se ke krajinnému rázu, př́rodní památce, ale i u institutu významného krajinného prvku, př́rodního parku a obecně u zvláště chráněných území, kde je zohledněno i hledisko estetické. ${ }^{3}$

Estetická hodnota krajiny samozřejmě nebyla jediným motivem $\mathrm{k}$ vyhlašování rezervací či ochrany přírodních památek - obecně se ale jednalo o kulturní hodnoty, na nichž se estetická hodnota podílela významně. Již od 19. století se také na motivech k ochraně prrírody podílel význam či hodnota př́rody/krajiny z hlediska př́rodních věd. Postupem času přírodní vědy v podstatě přejaly úlohu vedoucího myšlenkového pozadí pro ochranu př́rody. Mnozí se snažili postavit tuto činnost na čistě prírodovědecký základ spolu $s$ tím, že se značně proměnila témata i slovník této činnosti (hovoříme dnes především o ochraně biodiverzity, klimatu atd., nikoliv krásné skály, hory atp.).

Je jistě v pořádku, že jsou to přírodní vědy, kdo spolupůsobí při ochraně přírody, její praxi i teorii. Současně však v posledních desetiletích vzniká tlak na to, převést celou

3 Viz zákon 114/1992 Sb. Dá se říci, že tvưrci zákona věnovali estetickým hodnotám př́rody pozornost skutečně významnou. Estetické hodnoty jsou zmiňovány nejen u významného krajinného prvku ( $\$ 3 \mathrm{~b})$ či krajinného rázu $(\$ 12)$, ale obecně u celé kategorie zvláště chráněných území (\$14), která jsou definována př́mo jako „území prrírodovědecky či esteticky velmi významná nebo jedinečná“ $Z$ nich pak je estetická hodnota výslovně zmíněna ještě jednou u národní přírodní památky $(\$ 35)$ a přírodní památky $(\$ 36)$. V př́padě chráněné krajinné oblasti $(\$ 25)$ je v definici použita formulace: „rozsáhlá území s harmonicky utvářenou krajinou“. Pojem harmonie tradičně koření v estetické oblasti, i když dnes a zde je ho možné vykládat i s jinými akcenty (např. jako rovnováhu, navazující spíše na fyzikální představy). Člověk se až skoro diví, že v každém okresním městě či národním parku nesedí ze zákona nějaký estetik př́rody... 
agendu spojenou s ochranou přirody do kompetence prrírodních věd, a to $\mathrm{v}$ celosvětovém měřítku - viz i př́iklady britských území, kde se stále více uplatňuje exaktní metodika, snaha zobjektivizovat důvody pro ochranu té které scenérie. Novopositivistická tendence podřadit všechno pod exaktně zjistitelné údaje je více než patrná.

Přitom se zapomíná na to, že ochrana prírody, stejně jako ochrana památek, nejen byla, ale stále je, činnost navýsost společenská a kulturní - to lidé rozhodují o tom, co budou chránit a co ne, jakkoli to dělají i pro „prrírodu samu“. Vzhledem k dominanci euroatlantické civilizace a jejích idejí pak samozřejmě tyto tendence přejímají i kultury, které dříve prŕrodu nechránily vůbec, nebo byla „ochrana" motivována zcela jinými motivy - např. náboženskými, jako v př́padě míst či organismů, které jsou tabu atp. A tyto civilizace či kulturní okruhy budou chránit prírodu pouze do té míry, nakolik se nám podaři je přesvědčit, že i pro ně je ochrana přírody nějaká hodnota. To se třeba v př́ípadě tropického deštného pralesa ukazuje jako značně problematické pro drtivou většinu tamních obyvatel, nezvyklých uvažovat v globálním měřítku (které lidské psychice není vlastní). To se týká ale i „domorodého“ obyvatelstva v rámci naší euroatlantické civilizace, které často $\mathrm{s}$ nevolí či nepochopením sleduje uzavírání dosud př́stupných areálů z důvodů ochrany tamní prírody, musí omezovat podnikatelskou a průmyslovou činnost atp.

Paradoxem ,vědecké“ ochrany přírody je ovšem to, že se svým způsobem zř́iká argumentů, které jsou pro obyvatele naši i jiných kultur srozumitelné, a které pracují právě s emocemi a vůbec kulturními hodnotami - které jsou dnes často díky globalizované civilizaci sdíleny i značně odlehlými společnostmi. Ochrana biodiverzity, ale i řady př́írodních procesů jsou pro většinu lidí skutečně těžko pochopitelné a v konkrétních případech narážejí na odmítavou reakci. A nemusíme chodit ani za hranice - i u nás ochrana nějaké vzácné ropuchy, brouka, ale i samovolných procesů na Šumavě je problematická pro většinu místních obyvatel. Právě na př́kladě Šumavy je vidět, jak dalece jsou otázky ochrany spojeny jednak se společensko-kulturním konsensem, stejně jako s estetickými preferencemi - ošklivost krajiny s uschlými stromy je jedním z nejčastějších argumentů. ${ }^{4}$

Tendence řady ochranářů založit ochranu prrírody pouze na prírodovědných argumentech nutně narážejí - přes svou oprávněnost - na nepochopení i neporozumění právě tím, že pomíjí ochranu přírody jako činnost v podstatě kulturní. Tím není řečeno, že by př́rodní vědy neměly být zásadní při péči o konkrétní území, konkrétní organismy, ale to, že jejich kompetence už není zcela tak jednoznačná při výběru, o které území či organismus se bude a $v$ jaké míře pečovat. Při léčení jednotlivého pacienta je jistě třeba přenechat rozhodování na lékařích, vlastní směřování zdravotnictví i vůbec pojem zdraví je však již jev podstatně složitější a ve své podstatě celospolečenský.

Navíc, v řadě případů kompetence přírodních věd jednoduše nepostačují - především při ochraně krajinného rázu (v anglické oblasti landscape character), který je založen na ochraně krajin, kde se podílí jak prrírodní, tak kulturní prvky. Převést tyto aspekty jednoduše na př́rodovědou evidovatelné či pouze exaktně zjistitelné údaje je odsouzeno $\mathrm{k}$ neúspěchu, stejně jako snaha kvantifikovat vlastnosti uměleckých děl, které v nás vzbuzují estetické zalíbení či nikoli. Respektive je možné jistě nalézt některé obecné charakteristiky i měřitelné rysy, ale hodnotu konkrétního uměleckého díla (stejně jako hodnotu

4 Blíže k problematice estetického zalíbení v př́rodě ve spojení s „otázkou Šumavy“ v mém popularizujícím článku psaném pro Ekolist.cz [Stibral 2011]. 
krajinného rázu) lze „měřit“ jen v natolik hrubých rysech, že teorie na takových údajích založené většinou postrádají v praxi relevanci i schopnost predikce.

Tato problematika vztahu kulturních, resp. emocionálních, estetických i přírodovědných motivů ochrany přírody a jejich vzájemných vztahů (stejně jako přírodovědných či estetických hodnot prrírody) je samozřejmě značně rozsáhlá a zde se můžeme věnovat jenom omezenému okruhu, konkrétně právě estetickému. Text by rád přispěl především k diskusi nad možnostmi převést kulturní - v tomto případě estetické - hodnoty na empiricky, exaktně evidovatelné vlastnosti krajiny zjistitelné metodami přírodních věd. Navázal by tak na texty publikované na mezinárodním i domácím odborném fóru [např. Sheppard, Harshaw 2001; Gobster 1995; Vorel, Kupka 2010], kdy se s jistými rozpaky pokoušejí přírodovědně vzdělaní odborníci začlenit estetické hledisko do svých textů a které pak budí v některých př́ípadech někdy odpovědi až drtivě kritické z pozic estetických kruhů, jako např̀ v českém prostředí reakce na Míchalovy texty [Löw, Míchal 2003] od předního českého estetika Zusky [2009a, b].

Nejde mi o nějaké zásadní analytické stanovisko z pozic mého oboru, estetiky, spíše bych se $\mathrm{v}$ této eseji pokusil nabídnout určitý pohled, či spíše pohledy $\mathrm{z}$ této disciplíny. Rád bych především problematizoval pokusy vyrovnat se s estetickou hodnotou krajiny převedením kritérií či dat jednoho typu na jiný. Jinými slovy především snahu postavit ochranu přírody na co nejvíce „exaktních“ základech a údajích.

Samo toto úsilí je poměrně všeobecnou tendencí ze strany těch, kteří se ochranou přírody zabývají profesionálně a mají př́írodovědné vzdělání. Přitom jsou zjevně, jak se projeví při „soukromém rozhovoru“, motivováni k ochraně přírody především na základě emočních důvodů a hodnotových soudů, jejichž součástí jsou samozřejmě i soudy estetické. „Oficiálně“ však vystupují jako zastánci nejexaktnějších vědeckých poznatků.

Tento samotný rozpor však nechávám stranou, není mým cílem zkoumat míru estetické motivace u ochrany prŕrody, pouze podrobit kritickému pohledu některé teze snažící se propojit přírodovědou zjištěné vlastnosti ekosystémů, krajiny atp. s jejich estetickou hodnotou. Sami ochranáři se tak pokoušejí ze svého pohledu „pronést“ estetické hodnoty prrírody, které sami silně vnímají, i do ochrany přírody, která má být podle nich ale motivována přírodovědecky či alespoň na prrírodovědných základech postavena. Předmětem mého zkoumání na několika příkladech ale bude, zda se to, metaforicky řečeno, dá udělat skrze tyto „přírodovědecké dveře“, či zda by nebylo lepší si přiznat oprávněnost různých kritérií a motivů, nepřevoditelných jeden na druhý. Jakkoli osobní sympatie autora tohoto textu patří v mnoha ohledech př́rodovědcům i ochranářům, a je dalek toho popírat platnost některých biologických zobecnění, pokusí se ukázat na několika př́kladech problematičnost tohoto redukcionismu. Je podle něj totiž v podstatě zbytečné, aby se k němu zájemci o krásy př́rody, stejně jako přírodovědci i ochranáři uchylovali - ochrana prrírody přece může být (a vlastně už je) založena na přírodovědných $i$ estetických a dalších kulturních kritériích.

Estetické hodnoty chápu v tomto textu jako vzniklé v rámci lidské kultury, stejně jako estetické vnímání samotné (jakkoliv můžeme najít i jeho biologické kořeny). Estetický postoj je stále postojem zaujímaným v lidské kultuře, at již se jedná o estetické zalíbení (či odpor) k lidským výtvorům nebo prírodě. 


\section{Estetické hodnoty př́rody a její ochrana}

Rozpaky, s jakými přistupují př́rodovědci-ochranáři $\mathrm{k}$ estetické dimenzi, jsou převažující reakcí. Jak v jednom textu píše Ivan Dejmal, „navařili“ si navrhovatelé zákona (míněno o krajinném rázu) ${ }^{6}$ kaši, nebo také upadli do „pasti estetického soudu“, z níž se pak snažili utéct „popisem krajinných prvků, které tvoří krajinný ráz, tak kategoriemi vzácnosti, jedinečnosti, typičnosti nebo cizorodosti“ [Dejmal 2005: 5], které se přiznávají jednotlivým krajinným prvkủm či jejich kombinacím v určitém prostředí. Nemyslím si, že je kaše navařena špatně, ba se nedomnívám, že nějak zásadně špatně chutná, s rozpaky hledím však na její následnou konzumaci.

Takových př́íladů samozřejmě najdeme celou řadu, u nás by bylo dobré uvést kromě výše citovaného Dejmalova textu, kde se pokouší dávat estetickou hodnotu krajiny do souvislosti s její stabilitou, především Míchalovy pokusy [Míchal 2001; Löw, Míchal 2003]. Ve světovém kontextu zde uvedu především přírodovědně vzdělané osobnosti, stojící aktivně i myslitelsky za formováním ochrany přírody v 20. století - a to Aldo Leopolda, který se snažil převádět estetickou hodnotu krajiny především na biodiverzitu, a Konrada Lorenze, který zdůrazňoval naopak komplexnost.

V obecné rovině má tento typ př́stupu oprávnění, a také, nezapomínejme, velmi dlouhou tradici. Od antiky po novověk byla krása - chápaná ovšem často substancionálně, tj. jako objektivně existující - spojována s vhodností, dobrem, dokonalostí atp. Ale poté, co novověk přestal brát $\mathrm{v}$ potaz nezávislou existenci krásy jako ideje, univerzálie, přesunula se pozornost na studium estetické zkušenosti jako zkušenosti subjektu, který je jen do limitované míry závislý na objektivních vlastnostech vnímaných objektů. Estetická libost byla definována jako libost bez závislosti právě na nějakém zájmu, užitku, vhodnosti, dobru, ba dokonce proporci, symetrii atd. (Burke, Kant, Schiller, atp.). To jsou totiž vlastnosti, těšící rozum, nikoliv ale naši emocionální stránku. Však také ne každá užitečná věc je současně krásná (např. kanalizace, stř̌eva), stejně jako ne každý symetrický či podle zlatého řezu konstruovaný objekt $\mathrm{v}$ nás vzbuzuje pocit estetického zalíbení.

Tato velmi zásadní proměna chápání krásy ovšem nebyla přijata všemi, především pak př́rodovědnými kruhy, které dále hledaly a hledají nějaké „objektivně“ evidovatelné vlastnosti objektů (rozuměj měřitelné), které by měly vzbuzovat estetickou libost. Pokouší se najít základ pro naše estetické preference, především v evolucí formovaných preferencích v rámci př́rodního i pohlavního výběru [např. Appleton 1975; Eibl-Eibesfeldt 1984; Enquist, Arak 1994; Johnstone 1994; Roberts et al. 2004; aj.]7. Zásadnost př́rodo-

6 Hledisko estetické ve spojení s pojmem krajinného rázu - $\mathrm{s}$ ještě větším důrazem - bylo zohledněno již ve starším českém zákoně [Sklenička 2003: 134]. Tento pojem se totiž objevuje už v přídělovém zákoně č. 47/1920: „Př̌i sdělávání plánu přihlížej pozemkový úrad $\mathrm{k}$ tomu, aby přídělem nebyly rušeny krásy př́rodní a ráz krajinný... Pozemkový úrrad může k tomuto cíli svoliti, aby plochy, které jsou věnovány parkům, přírodním parkům, které slouží jinak k okrase krajiny, nebo jejíchž účelem jest zachovati ukázku původního rázu krajinného... vlastníku byly ponechány..."I pozdějš́ zákon 47/1948 pak uvádí: „Při pozemkových úpravách... bud zajištěna ochrana památek všech druhủ, přírodních krás a krajinného rázu.“

7 Uvádím pro př́klad jak citace knih, tak článků. S výjimkou zásadní Appletonovy práce zaměřené na krajinu jde o texty zaměřené především na estetické preference obecně s vazbou na evoluční vysvětlení. Vybrané př́klady tř́ časopiseckých odkazů by samozřejmě mohly být i zcela jiné, kniha Eibl-Eibesfeldtova je ale průkopnickou a obsáhlou monografí, zahrnující i kapitolu o estetických preferencích s nebývalým ohledem na filosofickou estetiku. 
vědných znalostí pro estetické hodnocení přírody však přijímají i někteří zastánci tzv. environmentální estetiky, zabývající se estetickým postojem k př́rodě, a není náhodou, že její zakladatel Allen Carlson se k Leopoldovi výslovně hlásí [Carlson 2002: 430].

\section{Biodiverzita, komplexita, stabilita...}

Z tohoto klimatu pak vycházejí názory i na př́rodu, resp. krásu přírody, především u řady ochranářů, kteří mají přírodovědné vzdělání a oprávněně se snaží v jeho rámci najít i odpovědi na otázky estetiky. Otázkou ovšem je, zda je oprávněné snažit se převést dimenzi, doménu určitého typu (kulturní) na úroveň jinou, resp. nižší (biologickou). Tento problém však nechme stranou.

Již Aldo Leopold naznačil ve svých textech (Sand County Almanac, 1949) [čes. Leopold 1999: 195-206] některá východiska „ekologické estetiky“, a i když nikdy explicitně nevypracoval nějakou systematickou estetiku, vychází řada textů [Calicott 1983; Gobster 1995; Gobster 1999; Gobster et. al 2007] z jeho zmínek a především ze souboru Leopoldových textů vydaných Fladerovou a Calicottem (The River of the Mother of God, 1991) [Flader, Calicott 1991a].

Stručně řečeno, Leopold či „leopoldovská estetika“ se staví do protikladu k pouhé „scénické estetice", založené na barvách a formách a scénických a malebných kvalitách [viz Flader, Calicott 1991b: 8-12; též Gobster et al. 1999: 57]. ${ }^{8}$ Hlubší estetický zážitek je dle Leopolda závislý na našem vědomí př́rodních procesů a znalostech ${ }^{9}$, např. jak se jedna část má k celku, jak se formy organismů objevily (evoluce) a jak přetrvávají (ekologie). Krása určité scenérie by podle něj souvisela proto s určitou ekologickou integritou a stabilitou.

Ještě krok za Leopolda jde dokonce současná větev estetiky, tzv. environmentální estetika [souhrnně nap̌r. Carlson 2002; Fisher 2005], která již př́mo tvrdí, že estetický zážitek z přírody jsou oprávněny prostředkovat právě přírodní vědy. Doposud byla př́íroda podle ní vnímána prizmatem umění, jako scenérie nebo objekt, něco vymezeného rámem či podstavcem apod. Tento dosavadní př́stup ale opomíjí dle této estetiky specifičnost právě zkušenosti s př́rodou, která nemá rámce ani podstavce, jsme v ní uvnitř̆, vše se proměňuje. Př́roda také nemá tvưrce, a jestli, tak zcela jiné kvality než má tvořící člověk. Jako podklad pro náš estetický postoj k př́rodě pak mohou sloužit jen disciplíny, zabývající se prrírodou a ne uměním, a tím jsou prrírodní vědy ${ }^{10}$ - pro pravý estetický zá-

8 Upřímně řečeno, není zcela vždy jasné, co a jak přesně Leopold myslel. Jeho Obrázky z chatrče sice dokonce obsahují celou kapitolu nazvanou „Estetika ochrany př́rody“ (Conservation aesthetics), ale je to spíše zajímavá a dodnes podnětná úvaha na téma rekreačního vztahu k volné př́rodě a i výše zmiňované „estetické“ názory tu nejsou prezentované v této podobě, tj. jako specificky estetické, ale týkající se obecně vnímání [viz Leopold 1999: 202]. Jeho názory na estetiku ale nalezneme ještě v dalších pracích, např. v přednášce „Land Patology“ z r. 1935 [Leopold in Flader, Calicott 1991a: 212-217].

9 Historickou paralelu bychom mohli vidět ve vủbec první práci věnované estetice prrírody, v Unterredungen über die Schönheit der Natur (1750) leibnizovského matematika, filosofa a př́rodovědce Johanna Georga Sulzera - pro něj je také pravá krása přírody založená na vědomí zde probíhajících procesů, ale především na reflexi celé harmonické konstrukce Vesmíru, vzájemné stabilitě, dokonalosti a nenahraditelnosti stvořených druhů - stojí ale za zmínku, že se opírá ovšem o představu př́rody kreacionistickou.

${ }^{10}$ Carlson dokonce uvádí tezi, která ovšem jen těžko může obstát před filosofií a dějinami vědy 20. století: „Věda je tím paradigmatem, které odhaluje objekty takové, jaké jsou, a s vlastnostmi, které mají. Nejenže se tedy projevuje jako zdroj objektivní pravdy, jiné př́stupy označuje jako subjektivní klamy, a tedy v souladu s objektivním oceňováním, jako irelevantní pro estetické oceňování..." [Carlson 

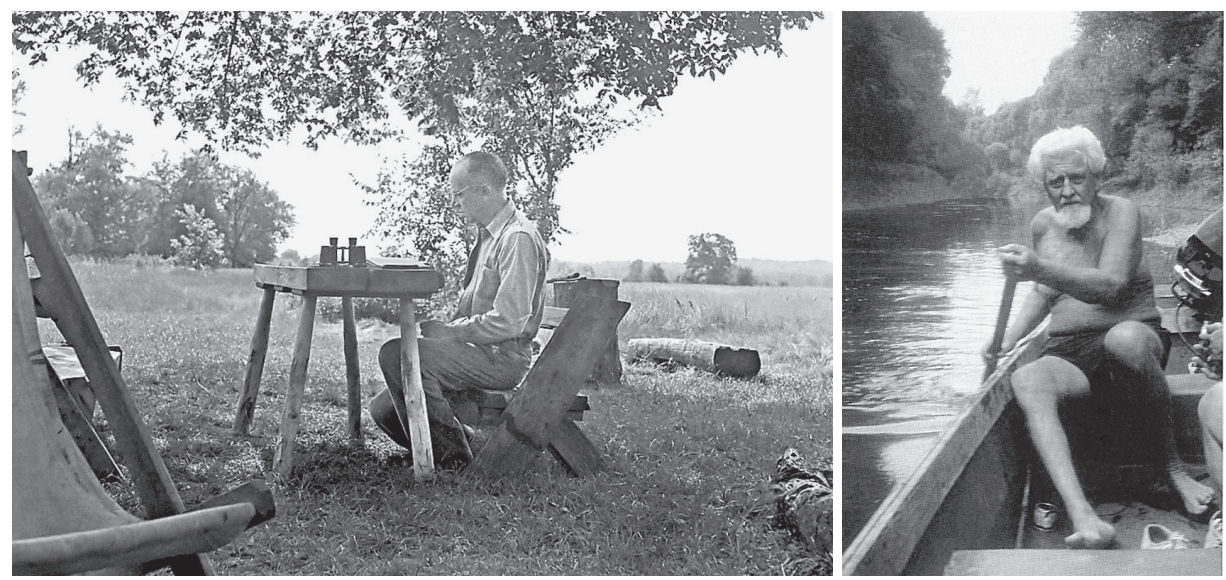

Obr. 2. a 3: Dvě velké osobnosti ochrany př́írody, které ve svém díle akcentovaly i estetickou dimenzi Aldo Leopold (v r. 1946) a Konrad Lorenz (kol. r. 1983).

žitek z přírody je třeba umět rozlišovat jednotlivé organismy, stejně jako znát procesy zde probíhající, mít představu o vzájemných vazbách, tedy ekosystémech, a vůbec pracovat s pojmy těchto disciplín, atd.

Zůstaňme ale u vlastních prrírodovědných kruhů. Obdobný př́istup jako u Leopolda najdeme u Konrada Lorenze, který byl nejen zakladatel etologie, ale i rakouské strany Zelených, nazývaný dokonce „Der Erste Grüne“. Lorenz sice také nenapsal samostatné pojednání o estetice, ale k tématu se vrací hned v několika svých dílech [viz Lorenz 1943; Lorenz 1997; Lorenz, Mündl 1992]. Oproti Leopoldovi je estetická dimenze pro něj značně významná a tomu odpovídá i podstatně promyšlenější přístup [blíže viz Stibral, Stella 2006].

Pro Lorenze je estetická reakce na prŕrodu jednou ze základních psychobiologických reakcí lidského druhu a vyplývá $\mathrm{z}$ hluboce zakořeněných a pro naše přežití zcela zásadních preferencí. Podle Lorenze hraje totiž zásadní roli při vzniku našich estetických preferencí vrozené estetické schéma, které je odvozené z obrazu zdravého zástupce vlastního druhu - jeho tvarů, proporcí, textury povrchu, barev, hlasového projevu, a které pak přenášíme i na další organismy - nap̌r. ropucha se nám nelíbí, protože její bradavičnatá kůže pro nás signalizuje onemocnění.

Lorenz stavěl své estetické názory především na poznatcích gestaltpsychologie, stejně jako na tradici goethovské biologie, aniž by ovšem nějak zásadně vystupoval vưči darwinistickému paradigmatu. ${ }^{11}$ Najdeme v jeho názorech jistou konzistentní syntézu těchto disciplín zahrnující jak psychologii, tak biologii darwinistickou i nedarwinistickou. Krás-

1993: 219] (překlad O. Dadejík, M. Kaplický). Již výchozí teze o tom, že věda poznává přírodu takovou, jaká skutečně je, je samozřejmě neudržitelná. Kritický pohled na Carlsonovu estetiku v češtině viz Dadejík a Kaplický [2009] a Kaplický [2009].

11 Lorenz se nicméně od řady biologů lišil v tom, že krásu, resp. estetické hodnoty explicitně odmítal redukovat na užitečnost s poukazem na řadu bezúčelných jevư v přírodě (třeba některé formy ptačího zpěvu). Současně výslovně kritizoval kantovský důraz na bezúčelnost krásy - proč by krása i užitečnost neměly být i pohromadě? Stejně tak odmítal novověké oddělení etiky a estetiky, pro něj obě oblasti tvořily kontinuum. 
ný organismus je pro Lorenze především celistvý, má jistou celkovou integritu, řekněme harmonii, stejně jako se vyznačuje dobrým zdravotním stavem. Hypertrofie a monstrozity narušují vrozené celky, estetické schéma (ästhetische Beziehunschema) a hodnotíme je jako ošklivé [viz Lorenz 1943: 281-290].

Toto tvarové vnímání, estetický cit, nám pak mohou napovídat podle Lorenze i v otázkách ochrany prrírody na úrovních celé krajiny - naše tvarové celostní vnímání nám pomáhá odlišit mezi zdravým a nemocným, tj. mezi krásou a harmonií na jedné straně a ošklivostí a disharmonií na straně druhé. Jako krásná se nám jeví krajina dostatečně diverzifikovaná, pestrá, druhově bohatá, stabilní, at se již jedná o krajinu kulturní nebo divokou. Naopak jako ošklivá se nám jeví nestabilní, devastovaná a monokulturní scenérie, ke které vede kořistnický zpo̊sob využívání př́rodních zdrojů.

„Ekologicky fundovaný člověk vidí rozdíl mezi krajinou vyznačující se přirozenou harmonií a krajinou, která je ohrožena devastací. Jeho podvědomí, celostní vnímání, mu umožňuje rozlišovat mezi harmonií a disharmonii' [viz Lorenz, Mündl 1992: 34]. Člověk ovšem musí vyrůstat obklopen živou harmonickou přírodou v citlivé a klíčové periodě dětství (imprinting), kdy se vrozené dispozice pro celostní vnímání „dolad'ují. Pokud je ale vystaven podnětům špatným, pak výsledkem $\mathrm{v}$ dospělosti bude v podstatě esteticky i eticky méněcenný jedinec: „Lidé, kteří jsou slepí k hodnotám tohoto světa - a počítám k nim také skoro všechny vysoce postavené průmyslníky - vyrostli většinou ve velkoměstech, kde jejich celostní vnímání dostalo jen málo informací o kráse př́rody“ [Lorenz, Mündl 1992: 38]. Pochopitelně, podotýká Lorenz, i zdevastovaná krajina se nakonec ustaví v nějakém stabilním stavu, který je určitým způsobem harmonický. Ve větru se vlnící velkolán i smrková monokultura mají též jistou estetickou hodnotu, která koreluje s komplexností. Tato hodnota (i stabilita) jsou však nesrovnatelné se starou mozaikovitou kulturní krajinou či původním smíšeným pralesem.

Míra estetické hodnoty podle Lorenze souvisí tedy i s množstvím nesené informace a komplexity. Vyšší typ řádu v živých organismech je krásnější. Plíseň pod mikroskopem se nám jeví jako pěkný ornamentální objekt, pokud však napadne např. květinu, zasáhneme ve prospěch „relativně vyšší harmonie rostliny a začneme bojovat s nižší harmonií houby“" [Lorenz, Mündl 1992: 37].

\section{Diskuse}

Takto bychom mohli pokračovat (zejm. v případě krajiny) výčtem různých přístupů dále, at již směrem k citacím ochranářủ (krásná je bohatá biodiverzita, stabilita, komplexnost ekosystému atd.), nebo směrem k názorům biologů či evolučních psychologů, tvrdícím, že máme preference pro typ krajiny podobný savaně, nebo obecněji typ nabízející výhled a úkryt, atd. [viz blíže Stella, Stibral 2009] Většinou se ale jedná bud’o spojení preferencí krajiny a organismů s jejich zdravím, komplexitou, biodiverzitou na jedné straně nebo spojení preferencí s nějakými vlastnostmi prostředí vhodnými pro činnost sběrače-lovce, vzniklé v průběhu vývoje rodu Homo. ${ }^{12}$ Obé je pak v podstatě často vnímáno jako jedno a totéž.

12 Jmenujme jako př́klady Appletonovu prospect-refuge theory a habitat theory [Appleton 1975], Oriansovu savannah hypothesis [např. Orians 1980], teorie Ulrichovy [1983, 1986] či komplexnější teorie manželů Kaplanových [Kaplan 1987; Kaplan 1992; Kaplan, Kaplan 1989]. 


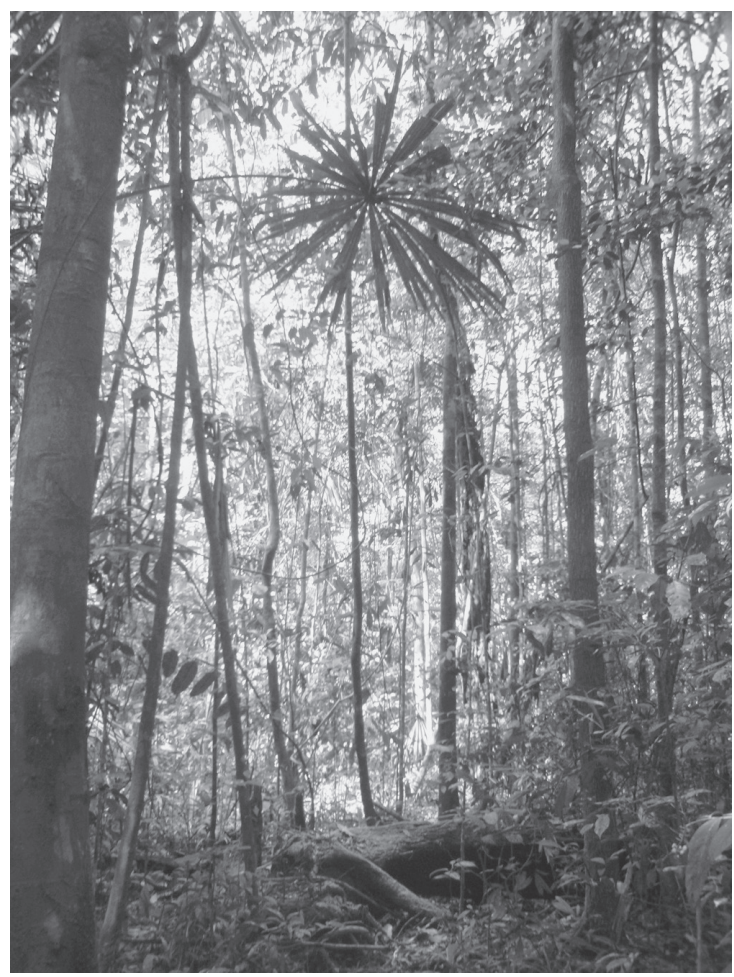

Obr. 4: Tropický deštný prales sice oplývá biodiverzitou, ale z estetického hlediska není vnímán většinou návštěvníkủ jako něco př́liš přitažlivého a hodnotného. Spíše naopak, většině lidí v minulosti i současnosti přišla nerozlišená změt listoví a kmenů ve stálém př́íšří vlastně nezajímavá a z estetického hlediska nesrovnatelná třeba s mozaikou kulturní krajiny, pochopitelně s výjimkou pralesních detailů, jako jsou květy či výrazně barevní živočichové (na obrázku primární deštný prales na jihovýchodním Borneu, lokalita Sungai Wain). Foto: Karel Stibral.

Upřímně řečeno, sám bych si přál, aby Lorenzovy závěry platily, velmi rád bych viděl souvislost mezi estetickou hodnotou krajiny a jejím zdravím a biodiverzitou, protože by to v řadě př́padů jak zjednodušilo rozhodování v konkrétních př́ípadech, tak i vysvětlování potřeby ochrany přírody laikům. Ǩada př́kladů by nás zdánlivě v našem přesvědčení o těchto souvislostech mohla utvrdit, ale když se na ně podíváme opravdu kritickým okem, je evidentní, že řada z Lorenzových tvrzení bohužel neobstojí, stejně jako obdobných idejí jiných myslitelů.

Podívejme se nejdřive na spojitost komplexity s krásou. Alespoň v takové podobě a př́kladech, jak ji uvádí Lorenz, vidíme bohužel na řadě př́kladů i opak. Na úrovni jednotlivých organismů je to nejzřetelněji patrné. Lorenzem zmiňovanou rostlinu budeme sice chránit před méně komplexní plísní, ale stejně tak před komplexnějǔím a vyšší harmonií obdařeným hmyzem či králíkem. Ve velmi obecné rovině do jisté míry asi i platí, že čím komplexnější organismy, tím se nám jeví být krásnější - živé organismy víc než neživé, obratlovci víc než bezobratlí, ptáci než plazi, atp. Tato hierarchizace je však natolik hrubá a má tolik vyjímek na úrovni nejen druhů, ale celých řádů (ba i samotných) tříd, že 


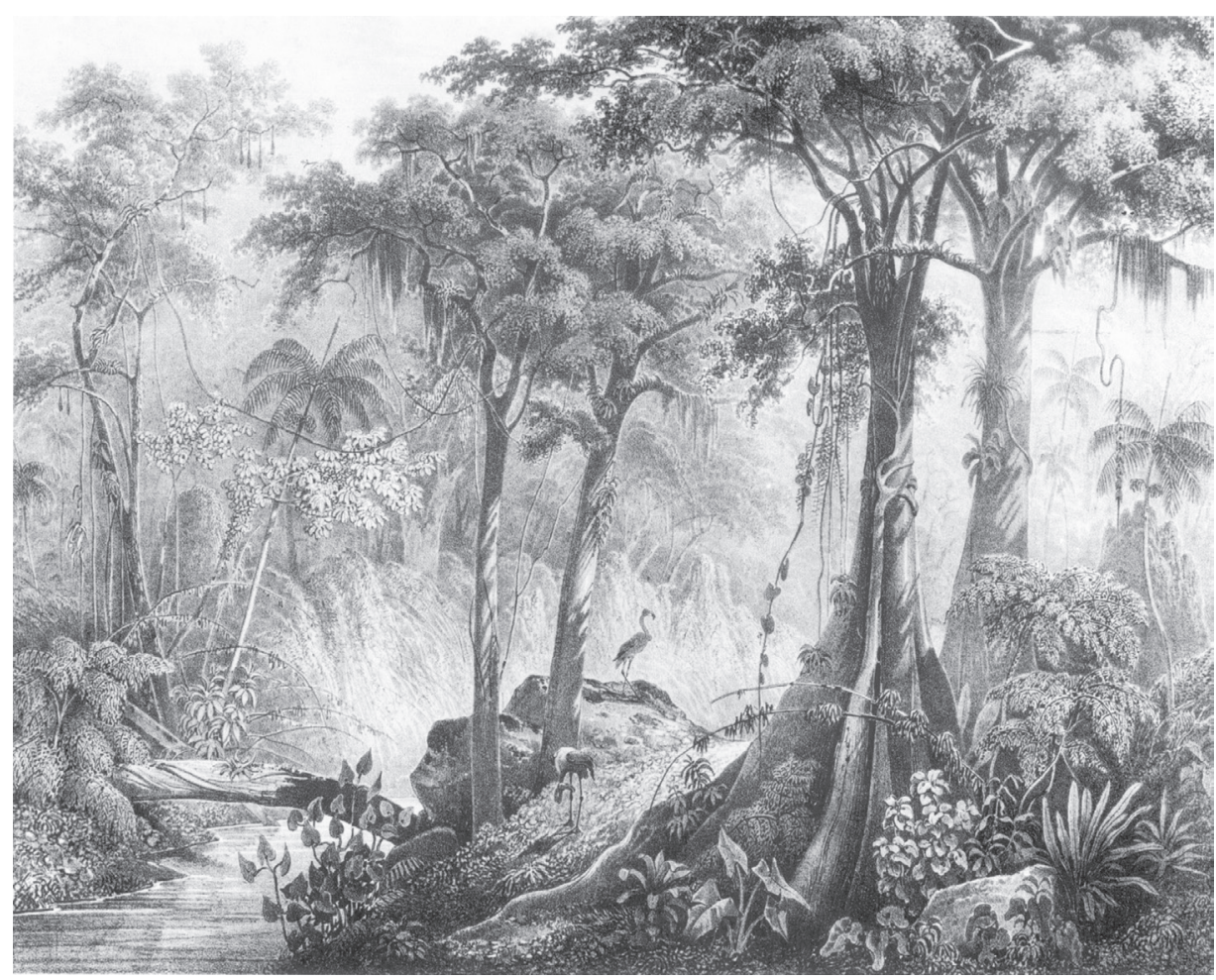

Obr. 5: Přesto i prales se stane jakýmsi prototypem přírodních krás, a to především díky líčení Alexandra von Humboldta a jeho následovníků z řad př́rodovědců (např. Darwina), ale i umělců, kteří ho zachytí v podobě, se kterou se „ve skutečnosti“ asi nesetkáme, a která vypadá nadmíru lákavě. To je ostatně i širší problém vztahu originálu a reprodukce - krajina na reprodukci ještě není krajinou samotnou a zalíbení v objektu zobrazeném se vůbec nemusí krýt se zalíbením v objektu „reálném“. Hory se na obrazech líbily dávno před tím, než ve skutečnosti, obraz staré žebračky může být krásný, nikoliv však žebračka samotná, atd. A to platí i pro fotografii, kde každý známe fenomén fotogenického obličeje, kdy dotyčný/á vypadá „lépe“ než ve skutečnosti, a naopak, schází jí objektivem nezachytitelný půvab. Přesto na tento jednoduchý rozdíl zapomínají přírodovědci, kteří často zkoumají estetické fenomény nikoliv na objektech samotných, ale na jejich zobrazení. (Litografie brazilského pralesa L. Deroye podle kresby oblíbeného Humboldtova výtvarníka J. M. Rugendase z 19. století.)

se pravidlo estetického zalíbení založené na komplexnosti nedá přijmout - neumožňuje totiž téměř žádnou predikci. Opravdu platí plazi za krásnější než ryby, savci než ptáci, opice než sudokopytníci či lichokopytníci? Spíše naopak. U konkrétních druhů či rodů již budeme zcela bezradní - u málokoho zvítězí v pomyslné soutěži krásy podstatně komplexnější vrápenec malý nad obyčejným „jednoduchým“ otakárkem fenyklovým, natožpak jeho tropickým př́buzným otakárkem Trogonoptera brookiana, kočkodan či potkan nad lyrochvostem či kanárkem atd.

Zdánlivě méně kontroverzní je toto výše zmíněné tvrzení v postoji ke krajině. Ale i tady najdeme celou řadu př́ikladů, kdy krajiny méně komplexní budou budit esteticky větší nadšení než složitější systémy - např. krása velehorských vrcholků a ledovců bude oceněna více ve srovnání s jednotvárným, ale stále komplexnějším lesem. 
Zde by se ovšem dalo argumentovat, že tvarová komplexita může nahradit komplexitu biologickou, ale tím již ztrácí tvrzení, nadřazující složitější (eko)systém nad jednodušší smysl, celý argument by se přenesl na jinou úroveň. Můžeme sice uvažovat o vzniku našich preferencí pro složitější systémy biologické (logicky komplexnějších tvarových struktur) a jejich následném „zmatení tvarovými strukturami, již nám ale pak takový estetický soud nemůže pomoci rozhodnout, která krajina je i biologicky zdravější a hodnotnější a popřel by tak základní tezi o možnosti odvozovat estetickou hodnotu z biologických vlastností. Na druhou stranu by nám tato tendence $\mathrm{k}$ preferenci složitosti těžko vysvětlovala opačnou zálibu v některých jednoduchých tvarech.

U biodiverzity (od diverzity genetické přes druhovou až po rozmanitost ve smyslu rozdílů mezi ekosystémy, mezi společenstvy, v typech prostředí atd.), která s komplexitou samozřejmě souvisí, je situace obdobná. Opět zdánlivě logická spojitost druhového (resp. ekosystémového, genetického) bohatství s estetickými hodnotami neumožňuje predikovat estetické zalíbení v jednotlivých konkrétních př́ípadech.

A to ani na úrovní biotopů či společenstev značné obecnosti. např̀. biodiverzitou oplývající tropický deštný prales nebudí nijak velké estetické nadšení. Pro mě osobně sice tento typ biotopu přináší jeden z největších estetických zážitků, ale jak z historických pramenů, tak z osobní zkušenosti s dalšími lidmi, a to i př́rodovědci, je zjevné, že nějak zvláštní estetické zalíbení obecně nevzbuzoval ani nevzbuzuje ( $\mathrm{k}$ tomu viz obr. 4 a 5). ${ }^{13}$

$\mathrm{U}$ konkrétních př́ípadů dojdeme často $\mathrm{k}$ řadě křiklavých nesouměřitelností biodiverzity a estetického zalíbení. např̀. u Máchova jezera prohrává z estetického hlediska bažina ${ }^{14}$ Swamp (viz obr. 6) s vysokou biodiverzitou s podstatně druhově chudším borovým lesem na podzolové půdě, pusté kamenné srázy Dachsteinu budí větší zalíbení než druhově bohatší zarostlý český kopeček.

Složitější otázka je se stabilitou daného prostředí - je opravdu zřejmé, že přechodné fáze „zarůstání', sukcese, destruovaného lesa či třeba břehu řeky (jedno jestli člověkem či slonem) budí opravdu nevelké nadšení. Možná, že by se estetická neatraktivnost pralesa dala svést i na to, že je to v podstatě biotop značně nestabilní - po odtěžení či vypálení je tenká úrodná vrstva velmi rychle ztracena. A i v rámci pralesa nadřadíme stabilnější primární prales nad přechodný sekundární.

Opět bychom ale asi našli problém při porovnávání některých jednotlivých prostředí či biotopů navzájem. Je tedy nejkrásnější ten nejstabilnější? Je snad mozaika pěkné české krajiny, udržovaná neustále zásahy člověka, stabilnější než poušt či tajga? Je obecně klimaxový stav esteticky hodnotnější než různá sukcesní stádia nebo uměle udržované stavy? Je březový nálet ošklivý? Není i poměrně stabilní krajina, jako třeba donekonečna se táhnoucí step, k uzoufání nudná a esteticky nezajímavá?

13 Estetické zalíbení v tropickém pralese (nejen třeba tropických ostrovech atp.) uvádí ve velké míře vlastně až Humboldt, ale třeba i Darwin. Oproti tomu třeba spoluobjevitel teorie př́rodního výběru Wallace ho líćí spíše jako nudný. Pro mnoho lidí je setkání s reálným pralesem (nikoliv ve filmu) zklamáním: malá viditelnost, př́íšrí, hustá splet rostlinstva a prakticky žádná barevnost na ně působí nudně. Bohatství biodiverzity zde není na první pohled patrné - rostliny jsou víceméně podobné, atraktivní hmyz či živočichové jsou většinou schovaní.

14 Estetické zalíbení $\mathrm{v}$ bažině je ještě pozdějš́ího data než $\mathrm{v}$ horách a pralesích a ve větší míře se dá datovat až do 20. století. Najdeme ale i dř́ve výjimky, nejčasnější jsem nalezl u Thoreaua [1925: 28]. I v sekundární literatuře nalezneme velmi málo textů věnovaných tomuto problému, v Čechách jsem nalezl jako výjimku jen Klvače [2003]. 


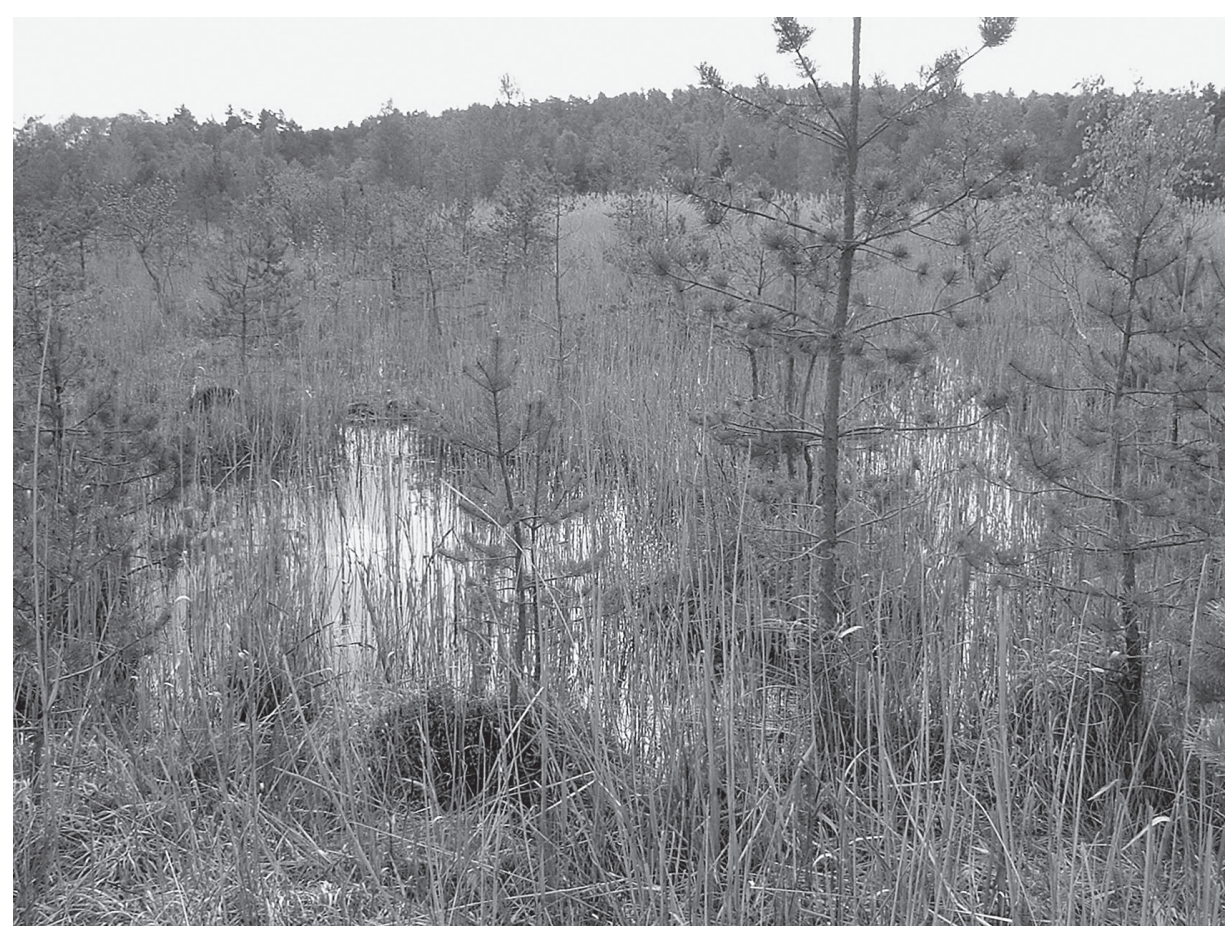

Obr. 6: Na biodiverzitu bohaté rašeliniště Swamp u Máchova jezera nevzbuzuje u kolemjdoucích žádné velké estetické zalíbení, zatímco okolní druhově chudá písečná krajina borových lesů je cílem mnoha výletníkủ a vyhledávanou rekreační oblastí. Foto: Jiří Neustupa - PřF UK.

Obdobně nezbývá než zpochybnit i názory na potřebu vědeckých znalostí pro estetický zážitek z krajiny, znalost jednotlivých druhů i ekologických procesů atp. A to jakkoli můžeme souhlasit $s$ tím, že naše estetické vnímání může být podpořeno těmito znalostmi. Naše znalost organismů, geologických podmínek, ekologických procesů atd. umožňují totiž vnímané pole lépe artikulovat, strukturovat, pomáhají zaměřit naši pozornost, abychom vůbec daný organismus, ekosystém atd. „uviděli“.

I když tedy můžeme přijmout podíl vědeckých znalostín ${ }^{15}$ na vzniku estetického postoje, problematické je to, co by z takové teze vyplynulo, kdybychom ji absolutizovali. Míra estetického zážitku by pak nutně rostla s mírou poučenosti př́rodními vědami. Př́rodovědec by tedy krásu prrírody dovedl ocenit více než laik i umělec, entomolog by byl jediný schopný posuzovat krásu otakárka i ploštice, protože zbytek populace o hmyzu z hlediska přírodních věd neví doslova nic, dendrolog by jediný měl skutečný estetický zážitek ze stromů, zatímco zbytek lidstva jen pouze mlhavý. Nadšení lidí 18. století prrírodou, stejně jako třeba romantiků, by bylo vzhledem ke stavu tehdejších prrírodních věd velmi omezené, nižší než naše. A to přes to, že bylo nejen pro ně samotné evidentně důležitější než pro nás. Obdobně bychom mohli u starých Č́ínanů, ještě méně znalých věd, shledávat

15 A nemusí to být znalosti pouze vědecké - třeba poznatky o růstu rostlin můžou spočívat na zahradnických, bylinkářských či lesnických znalostech, které se vytvářely už dávno před příchodem novověké vědy. 
ještě méně libosti z přírodních scenérií. Caspar David Friedrich ${ }^{16}$, romantický malír odmítající vědecké znalosti by pak z př́rody měl potěšení menší než leckterý tehdejší důlní či lesnický inženýr atd. Dostáváme se jednoduše do naprostých rozporů s evidencí jak ze současnosti, tak $\mathrm{z}$ minulosti.

Ono to totiž může být navíc i naopak - přílišný vhled do znalosti procesů, mezidruhových vztahů i shopnosti identifikace taxonů atd. může stejně tak znemožňovat estetické zalíbení. Př́rodovědec, alespoň podle reflexe vnímání u řady z nich, musí totiž „přepnout“, a toto přepnutí na estetický modus vnímání mu může být naopak „základním nastavením“ na teoretický postoj i ztíženo. Takové zaujetí, odbornost, může naopak vést naše vnímání ke sledování pouze určitých organismů, určitých procesů. Mưže se stát, že nevidím pro stromy les, nevidím pro př́lišné soustředění na detail celek (viz reprodukovaný Friedrichův obraz Útesy Rujanské - obr. 7).

Jakkoli mám sympatie k těm, kteří se zabývají př́rodou (a nikoliv pouze lidmi a jejich díly), nejsem si vưbec jist, že by k vnímání krásy růže nebo lesa byla nezbytně potřebná botanika. ${ }^{17}$ Stejně jako je otázkou, zda je nutná jiná (než vědecká) znalost - tou může být čistě praktická zkušenost a informace o terénu. Ty nám opět umožní sice v př́rodě zaměřovat pozornost, ale ten, kdo vnímá všechno $\mathrm{v}$ přírodě pouze $\mathrm{z}$ funkčního hlediska je často doslova slepý k jejím krásám. Estetický postoj potřebuje právě „vystoupení $\mathrm{z}$ postoje teoretického či praktického. At již se v lese věnuji fytocenologii, sbírám houby a borůvky, lovím zvěř či kácím dříví, musím si dát na estetické potěšení „pauzu“, abych mohl vnímat i jeho krásu, musím poodstoupit ze své dosavadní aktivity a přejít do estetického postoje.

Vůbec je i otázkou, zda vědecké metody mohou přinést nějaké všeobecně platné definice estetických soudů či všeobecně platná zjištění. A to nejen u výše jmenovaných přírodních věd. I vědecké metody ze sociálních věd ke zjištování krásy je totiž třeba brát s rezervou. Může nám sociologický výzkum přinést něco více, než zjištění, že určitá skupina obyvatel daného prostoru a času považuje věc za krásnou atp.? Pokud by takový přístup platil, bylo by to dobré - v zjednodušené podobě by pak stačilo udělat dostatečný sociologický dotazník na krásu toho kterého typu terénu a byli bychom tak schopni vlastně zjištovat i další kvality daného kraje. Ale opravdu rozhodne třeba o kvalitě uměleckého díla jeho co nejširší obliba? Jsou tedy telenovely vrcholem lidského uměleckého snažení a bestsellery červené knihovny vrcholem literatury?

$\mathrm{Na}$ druhou stranu, osobně si myslím, že biologické teorie můžou přinést leccos zajímavého, ale spíše ve vztahu ke krajině než k jednotlivým př́rodním objektům. Jmenoval bych zde např. Wilsonův koncept biofilie [Wilson 1984; Librová 2006], zalíbení v živém, nebo zjištění Kaplanových, jaké vlastnosti krajiny nás přitahují a činí ji v našich očích krásnou (komplexita, spojitost, čitelnost, tajemství) [Kaplan, Kaplan 1989]. Ale i zde narážíme - alespoň z hlediska nějaké „objektivní vědy“ - na nepřevoditelnost některých kritérií na jednoduché charakteristiky. Třeba pojem tajemství u Kaplanových, ale i pojem

${ }^{16}$ Friedrich byl jedním z mála romantiků, kteří př́rodovědné znalosti odmítali. V rozporu s obecně vžitou představou romantiků jako emocionálně založených lidí však většina projevovala o přírodní vědy eminentní zájem. Pod tehdejší př́ŕrodní vědou, zejména v našem německojazyčném okruhu, je třeba však rozumět především naturfilosofii.

17 Viz Kantův citát: „Květiny jsou svobodné př́rodní krásy. Co květina vskutku má být, kromě botanika stěží někdo ví, ale ani botanik, který na ní dokáže poznat rozmnožovací orgán rostliny, nebere na tento př́rodní účel žádný ohled, soudí-li o květinách na základě vkusu“ [Kant 1975: 69]. 


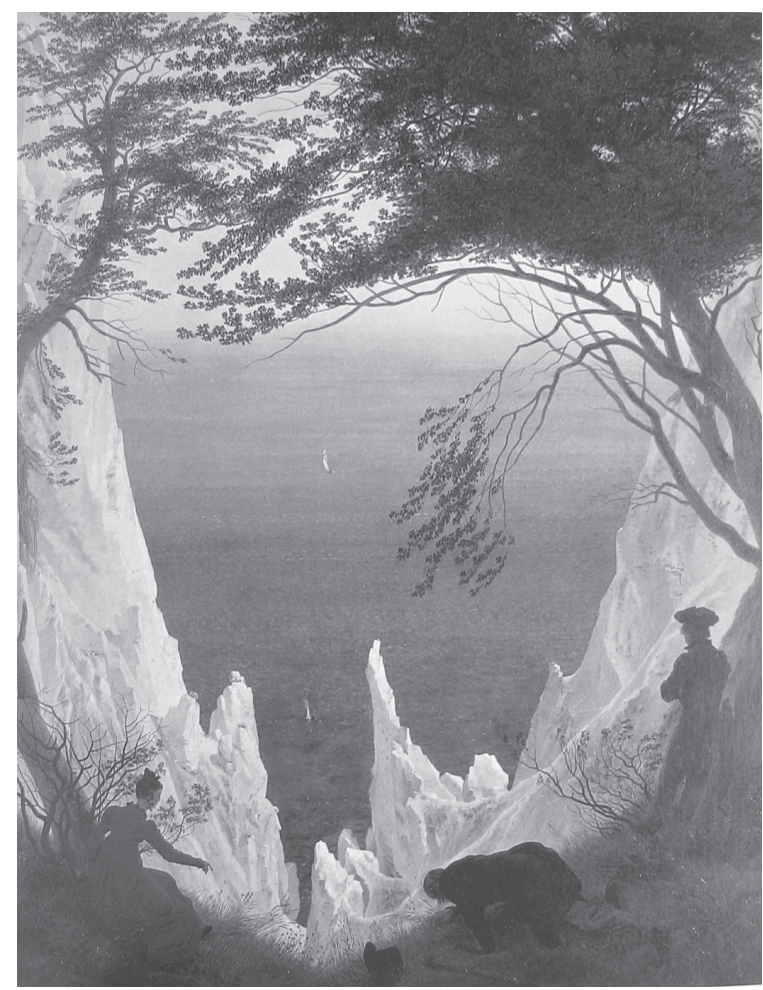

Obr. 7: Na obraze Křídové útesy na Rujáně (kol. 1818) ilustruje romantický malír Caspar David Friedrich odlišný prrístup $\mathrm{k}$ prrírodě - zatímco muž skloněný k zemi je vědec, který pro analytické studium detailu vlastně krajinu kolem sebe ani nevnímá, muž vpravo (snad Friedrich sám) př́rodu kontempluje jako celek. Friedrich odmítal přírodovědné znalosti, nebot podle něj mezi objektivním př́ístupem vědy a subjektivním citem malíře existuje nepřekonatelná propast. Znamená to tedy dle Carlsona, že měl minimální estetické potěšení z pohledů na krajinu?

živosti v rámci biofilie u Wilsona. Protože Wilson správně ukazuje, že jde o dojem živosti, co se nám líbí, nikoliv sám život, takže se nám mủže jako živá a tedy esteticky přitažlivá jevit např. měnící se obloha. Neodporuje to pak ale zase požadavkům na stabilitu a vůbec nějaké měřitelné hodnoty?

Problémem obdobných př́rodovědných teorií je také již zmiňovaná schopnost predikce, tedy požadavek, který poměřuje kvalitu té které teorie. Jak jsme již psali s kolegou Stellou v jiné práci o estetických preferencích krajiny z pohledu evoluční psychologie [Stella, Stibral 2009], není možné jednoduše přijmout některé teorie jak $\mathrm{z}$ důvodů čistě faktických, tak i z důvodu, že nabízejí př́liš široké a téměr nicneříkající závěry. Např. Appletonova prospect-refuge theory [Appleton 1975], tvrdící, že člověk má zálibu v krajině nabízející výhled i úkryt, umožňuje za krásnou označit velmi široké rozpětí scenérií od kulturní české krajiny přes africkou savanu až po francouzský park. Jistě nám umožní vyloučit některé typy scenérií, jako třeba prales. $\mathrm{V}$ tomto př́padě se ovšem dostaneme do rozporu s preferencí biodiverzity proklamovanou jinými teoriemi. A je vůbec takové obecné zjištění použitelné při rozhodování o konkrétních krajinách, neřku-li o jejich ochraně? 


\section{Závěrem}

Předchozí text se pokusil na několika případech sledovat, zda je možné uchopit estetické hodnoty prrírody skrze přírodovědou zjištované vlastnosti (krajiny i prŕrody obecně). Na základě minimální schopnosti predikovat jednotlivé př́ípady, ba i jistých vnitřních rozporů se zdá, že teorie tohoto typu, zmiňované některými environmentálními mysliteli nejsou udržitelné. Alespoň v současné podobě, samozřejmě - vývoj přírodních věd a biologie zvlášṫ nám jistě přinese ještě četná překvapení.

Je ale toto spojení či zjištění (estetických a „přírodovědných“ hodnot, jako je biodiverzita, komplexita atp.) vůbec potřebné pro vlastní ochranu přírody? Jistě by bylo dobré vědět, že pokud považuji nějakou krajinu za pěknou, obdivuji určitý krajinný ráz, můj estetický smysl mě současně informuje o biologických hodnotách krajiny. Domnívám se, že toto spojení by splňovalo přání především těm, kteří považují ochranu přírody za čistě přírodovědnou záležitost, ba dokonce za vědu, ale současně pocitují vưči přírodě i silné estetické zalíbení. To poslední ovšem považují „pouze“ za něco subjektivního, méně hodnotného. Přebírají tak názory (neo)positivistické vědy, která upírá v podstatě hodnotu čemukoliv, co není měřitelné a převoditelné na nějaké „empiricky“ ověřitelné hypotézy a neměnné zákony. Osobní pocity a emoce hrají v takovém světě, kde mají význam pouze „objektivni“ fakta, pouze podružnou roli.

To je ale cesta, která jednak popírá vývoj ve vědě samotné i v teorii vědy, kde se positivismus stal již minulostí a touha po objektivně platných faktech a datech překonanou. Současně podobný přístup ale popírá i to, co vlastně ochrana přírody vlastně je - nikoliv přísně vědeckým oborem, ale na kulturních hodnotách založenou a těmito hodnotami podmíněnou disciplínou, která využívá informací z přírodních věd.

Zjednodušeně řečeno, měli bychom si přiznat, že ochrana přírody je kulturní záležitost (jak upozorňuje z našich př́rodovědců např. David Storch [2011]), a nehledat pouze nějaká závazná př́rodovědná kritéria. Estetická hodnota krajiny přece je také významný důvod pro její ochranu! To plyne i z tak prostého faktu, že ochraňujeme v našich podmínkách především krajinu kulturní. Ostatně, po některých rozhovorech s biology i ochranáři se domnívám, ze tř̌eba vyhlášení řady různých rezervací či ochrany některých organismů je minimálně spoluformováno našimi estetickými preferencemi. Často se chrání organismy i místa „krásnější. Pěkná květina či pták si evidentně naši ochranu vyslouží většinou častěji než mnohem vzácnější nenápadný hnědý brouček či téměř neviditelná terestrická řasa. A připomeňme si také historickou tradici $-\mathrm{z}$ textů $\mathrm{z}$ doby zakládání prvních rezervací u nás (Žofínský prales), ale i jinde (tř̌eba Yellowstone či v úvodu jmenovaná území chránící Scenic Beauty v Británii), je patrná motivace primárně kulturní, nikoliv př́rodovědecká.

Samozřejmě, problematický začne být kulturní přístup v praxi, protože zdánlivě neumožňuje jednoduchá řešení zaštítěná přírodovědeckými fakty (zde je potřeba chránit biodiverzitu, jinde unikátní ekosystém...). ${ }^{18}$ A to se týká samozřejmě i legislativní úpravy, u které jsme vlastně celý text začínali. Zákon je ale především formulace etických pravidel a sankcionování jejich porušování. Etická pravidla, stejně jako estetická hodnota či funkce

18 Pomiňme ovšem fakt, že i takto motivované ochranářství se dostává do sporů a odlišných expertních názorů - viz spor mezi zastánci handsfree managementu a zastánci zásahů. 
se ovšem proměňují, stále se sjednávají. Neznamená to přece, že když u etiky a estetiky nejsem schopen formulovat „věčné“ závěry ve stylu přírodních věd v podobě nějakých jednoduše ověřitelných hypotéz, nebo dokonce nějakých vzorcem popsatelných zákonů, že tato oblast neexistuje, nebo že je to pouze jakási „dojmologie“. Naopak! Neznamená to ale samožrejmě také, že můžu v humanitních disciplínách tvrdit postmoderně všechno, co mě napadne, bez racionální a logikou vedené argumentace - můžu především vyloučit nesprávná tvrzení či přístupy a omezit chybná řešení. A k tomu estetika jako disciplína jistě může přispět, jakkoli se od ní nedají čekat nějaké „objektivni““ a na vždy platné pravdy. ${ }^{19}$

\section{LITERATURA}

Appleton, Jay. 1975. The Experience of Landscape. London: J. Wiley and Sons.

Binka, Bohuslav. 2011. „Karel Hynek Mácha, evoluční ontologie a Larry Laudan.“ Pp. 159-164 in Josef Šmajs (ed.) Aby země nebyla jen hrobem. Literatura, kultura, př́roda. Brno: Obec spisovatelů.

Calicott, J. Baird. 1983. „Leopold's land aesthetics.“ Journal of Soil \& Water Conservation 38 (3): 329-332.

Carlson, Allen. 1993. „Appreciating Art and Appreciating Nature.“ Pp. 199-227 in Salim Kemal, Ivan Gaskell (eds.). Landscape, Natural beauty and the Arts. Cambridge: Cambridge University Press.

Carlson, Allen. 2002. „Environmental aesthetics.“ Pp. 423-436 in Berys Gaut, Dominic McIver Lopes (eds.). The Routledge Companion to Aesthetics. London, New York: Routledge.

Dadejík, Ondřej, Martin Kaplický. 2009. „Kritika kognitivní estetiky př́rody Allena Carlsona.“ Pp. 47-54 in Karel Stibral, Bohuslav Binka, Ondřej Dadejík (eds.).: Krása, krajina, př́roda II. Brno: Masarykova univerzita.

Dejmal, Ivan. 2005. „Krajinný ráz aneb proč jsme si tuto kaši navařili.“ Pp. 5-6 in Tvář naší země - krajina domova, sv. 5 - Krajinný ráz. Lomnice n. Popelkou: J. Bárta Studio JB.

Eibl-Eibesfeldt, Irenäus. 1984. Die Biologie des menschlichen Verhaltens. München: Piper.

Enquist, Magnus, Anthony Arak. 1994. „Symmetry, beauty and evolution.“ Nature 372: 169-172.

Fisher, John A. 2005. „Environmental aesthetics.“ Pp. 667-678 in Jerrold Levinson (ed.) The Oxford Handbook of Aesthetics. Oxford: Oxford University Press.

Flader, Susan L., J. Baird Calicott (eds.). 1991a. The River of the Mother of God: And Other Essays by Aldo Leopold. Madison, Wisc., London: University of Wisconsin Press.

Flader, Susan L., J. Baird Calicott. 1991b. „Introduction.“ Pp. 3-31 in Susan L. Flader, J. Baird Calicott (eds.) The River of the Mother of God: And Other Essays by Aldo Leopold. Madison, Wisc., London: University of Wisconsin Press.

Gobster, Paul H. 1995. „Aldo Leopold’s Ecological Aesthetic. Integrating Esthetic and Biodiversity Values." Journal of Forestry 93 (2): 6-10.

Gobster, Paul H. 1999. „An Ecological Aesthetic for Forest Landscape Management.“ Landscape Journal 18 (1): 54-64.

Gobster, Paul H., Joan I. Nassauer, Terry C. Daniel, Gary Fry. 2007. „The shared landscape: what does aesthetics have to do with ecology?" Landscape Ecology 22: 959-972.

Jahn, Ilse (ed.). 2000. Geschichte der Biologie. Heidelberg and Berlin: G. Fischer.

Johnstone, Rufus A. 1994. „Female preference for symmetrical males as a by-product of selection for mate recognition." Nature 372: 172-174.

19 Míchal s Löwem uvažují mj. o laických (statistickém výsledku výzkumu názorů relevantní skupiny laiků) či expertních soudech o krajině [2003: 95]. Na rozdíl od nich se přikláním spíše k nějakým expertním soudům. Jak jsem psal již výše, sociologický průzkum nám nemůže úplně sloužit jako kritérium rozhodování o věcech estetiky. Stejně tak by se neměli kromě př́rodovědců ke krajině vyjadřovat pouze architekti, kteří jsou z titulu své profese ovlivněni zcela určitým typem preferencí a vnímacích rámců, a uvažují především v kategoriích krajiny zastavěné. Bylo by dobré dát slovo i odborníkům s jiným typem vnímání, jako jsou výtvarní umělci (např. land artu), fotografové, estetici atp. 
Kant, Immanuel. 1975. Kritika Soudnosti. Praha: Svoboda.

Kaplan, Steven. 1987. „Aesthetics, affect, and cognition: Environmental preference from an evolutionary perspective." Environment and Behaviour 19 (1): 3-32.

Kaplan, Rachel, Steven Kaplan. 1989. The Experience of Nature: A Psychological Prespective. New York: Cambridge University Press.

Kaplan, Steven. 1992. „Environmental preferences in a knowledge-seeking, knowledge-using organism.“ Pp. 581-598 in Jerome H. Barkow, Leda Cosmides, John Tooby (eds.). The Adapted Mind: Evolutionary Psychology and the Generation of Culture. Oxford: Oxford University Press.

Kaplický, Martin. 2009. „Carlsonova environmentální estetika: problematika estetického hodnocení př́rody a umění." Pp. 42-49 in Karel Stibral, Bohuslav Binka, Ondřej Dadejík (eds.). Krása, krajina, príroda I. Praha: Dokořán.

Klvač, Pavel. 2003. „Bažina a mokřad - dvě tváře divočiny.“ Biograf 30: 37-52.

Komárek, Stanislav. 1997. Dějiny biologie. Praha: Vesmír.

Leopold, Aldo. 1991. „Land Pathology.“ Pp. 212-217 in Susan L. Flader, J. Baird Calicott (eds.). The River of the Mother of God: And Other Essays by Aldo Leopold. Madison, Wisc., London: University of Wisconsin Press.

Leopold, Aldo. 1999. „Estetika ochrany přírody.“ Pp. 195-206 in Obrázky z chatrče a rozmanité poznám$k y$. Místo neuvedeno: Abies.

Librová, Hana. 2006. „O biofilii.“ Pp. 8-13 in Pavel Klvač (ed.). Člověk a les. Brno: Masarykova univerzita.

Lorenz, Konrad. 1943. „Die angeborenen Formen möglicher Erfahrung.“ Zeitschrif für Tierpsychologie 5: 235-409.

Lorenz, Konrad, Kurt Mündl. 1992. Zachraňme naději (Rozhovory s K. Lorenzem). Praha: Panorama.

Lorenz, Konrad. 1997. Odumírání lidskosti. Praha: Mladá fronta.

Löw, Jiří, Igor Míchal. 2003. Krajinný ráz. Kostelec nad Černými lesy: Lesnická práce.

Míchal, Igor. 2001. „Proti estetickému nihilismu při zásazích do krajiny (hodnocení krajiny, estetický teorém a snímky Miloše Spurného)."Pp. 52-59 in Tvář naší země - krajina domova. Lomnice n. Popelkou: J. Bárta Studio JB.

Orians, Gordon H. 1980. „Habitat selection: general theory and application to human behavior." Pp. 49-66 in Joan S. Lockard (ed.). The Evolution of Human Social Behavior. New York: Elsevier.

Rádl, Emanuel. 1909. Dějiny vývojových theorií v biologii XIX. století. Praha: J. Laichter.

Roberts, Craig S., Jan Havlicek, Jaroslav Flegr, Martina Hruskova, Anthony C. Little, Benedict C. Jones, David I. Perrett, Marion Petrie. 2004. „Female facial attractiveness increases during the fertile phase of the menstrual cycle." Proceedings of the Royal Society of London. B (Suppl.) Biology Letters 271:270-272.

Sheppard, Stephen R. J., Howard W. Harshaw (eds.). 2001. Forests and Landscapes: Linking Ecology, Sustainability, and Aesthetics. IUFRO Research Series, No. 6. Wallingford: CABI Publishing.

Sklenička, Petr. 2003. Základy krajinného plánování. Praha: N. Skleničková.

Stella, Marco, Karel Stibral. 2009. „Krajina a evoluce? Evolučně-psychologické teorie percepce krajiny. “ Envigogika 2. [online] [cit. 12.5.2011] Dostupný z: http://www.envigogika.cuni.cz/texty/20092/318-krajina -a-evoluceq-evolun-psychologicke-teorie-percepce-krajiny.

Stibral, Karel, Marco Stella. 2006. „Konrad Lorenz - od estetiky k ochraně př́rody.“ Estetika 1-3: 4-18.

Stibral, Karel. 2011. „Líbí se nám uschlý les? Slovo estetika k Šumavě.“ Ekolist.cz [online] publikováno 16. 8. [cit. 11. 9. 2011]. Dostupný z: http://ekolist.cz/cz/publicistika/eseje/libi-se-nam-zeleny-les -slovo-estetika-k-sumave.

Storch, David. 2011. „Odhady poklesu globální biodiverzity jsou naprostá hausnumera.“ Ekolist.cz [online] publikováno 17. 1. [cit. 11. 9. 2011]. Dostupný z: http://ekolist.cz/cz/publicistika/rozhovory /david-storch-odhady-poklesu-globalni-biodiverzity-jsou-naprosta-hausnumera.

Thoreau, Henry D. 1925. „Chůze, “ in Toulky přírodou a pohledy do společnosti. Praha: J. Laichter.

Ulrich, Roger S. 1983. „Aesthetic and affective response to natural environment." Pp. 85-125 in Irwin Altmann, Joachim F. Wohlwill (eds.). Behavior and the Natural Environment. New York: Plenum.

Ulrich, Roger S. 1986. „Human response to vegetation and landscape.“ Landscape and Urban Planing 13 (1): 29-44.

Vorel, Ivan, Jiř́ Kupka. 2010. „Estetická hodnota nebo vizuální atraktivnost krajiny.“ Pp. 104-116 in Ivan Vorel, Jiří Kupka (eds.). Aktuální otázky ochrany krajinného rázu. Praha: ČVUT.

Wilson, Edward O. 1984. Biophilia. Cambridge, Mass.: Harvard University Press. 
Zuska, Vlastimil. 2009a. „Krajinný ráz a ,lidová estetika.“ Pp. 243-249 in Karel Stibral, Ondřej Dadejík, Vlastimil Zuska. Česká estetika př́rody ve středoevropském kontextu. Praha: Dokořán.

Zuska, Vlastimil. 2009b. „Krajinný ráz a ,lidová estetika.“ Pp. 22-28 in Pavel Klvač (ed.). Člověk, krajina, krajinný ráz. Brno: Masarykova univerzita.

\section{SUMMARY}

This paper deals with the connections between the aesthetic value of nature, and landscape and ecosystem characteristics currently determined by the natural sciences to be important for nature conservation (biodiversity, complexity and stability). The paper shows the historical roots of nature conservation in Romantic reactions to nature, which were strongly related to aesthetic values. It also points out contemporary tendencies to protect aesthetically valuable natural areas (see for example British Areas of Outstanding Natural Beauty and National Scenic Areas). It points out the current dilemma about nature conservation for the sake of aesthetic landscape values and current attempts to transfer aesthetic values to values ascertainable using the natural sciences.

The essay presents several traditional attempts (Leopold, Lorenz) at connecting the beauty of nature with characteristics ascertained using the methods of natural science, yet it also discusses current biological knowledge. The discussion about the approach of natural sciences is led primarily from the perspective of aesthetics as a discipline. However, it also takes into account the incongruity of specific examples used in the arguments of natural scientists, as well as their inability to predict what type of landscapes will appeal to people. In the conclusion the idea that there is a definitive connection between the aesthetic value of nature and landscape and the biodiversity, stability and complexity therein is brought into question. At the same time though the paper admits that biological theories and approaches have a certain validity that is, however, so general (in that they include such a broad field of phenomena), that they do not allow for decision making in specific cases dealing with nature conservation. 